\title{
OXYURA LEUCOCEPHALA (ANATIDAE: ANSERIFORMES) ON THE BLACK SEA COAST OF THE CAUCASUS
}

\author{
Petr A. Tilba ${ }^{1}$, Lev M. Shagarov ${ }^{2,3}$, Victor I. Malandzia ${ }^{4}$ \\ ${ }^{1}$ Sochi National Park, Russia \\ e-mail:ptilba@mail.ru \\ ${ }^{2}$ Natural Ornithological Park in the Imeretinskaya Lowland, Russia \\ ${ }^{3}$ Branch of the Institute of Natural and Technical Systems, Russia \\ e-mail:lev049@mail.ru \\ ${ }^{4}$ Abkhazian State University, Republic of Abkhazia \\ e-mail:malandzia@mail.ru
}

Received: 01.04.2018

\begin{abstract}
New information on the distribution of Oxyura leucocephala on the Black Sea coast of the Caucasus is provided. The first appearance of the species in this region was recorded in 1991. At present Oxyura leucocephala is a small wintering and migratory species found on the Black Sea coast of the Krasnodarsky Krai (Russia) and Abkhazia. Single individuals or pairs of birds are usually noted, less often groups of up to ten white-headed ducks. The most significant was the wintering of Oxyura leucocephala on the lakes of the natural ornithological park in the Imeretinskaya lowland (Sochi, Russia) in 2016-2017. An assumption is being made about the formation of a new wintering area for Oxyura leucocephala occupying the northeastern coast of the Black Sea.
\end{abstract}

Key words: Abkhazia, Black Sea, Caucasus, migration, Novorossiysk, Sochi, white-headed duck, wintering

The white-headed duck Oxyura leucocephala Scopoli, 1769 (Anatidae, Anseriformes) refers to a widespread species inhabiting the southern part of Eurasia and North-West Africa. However, its breeding area is divided and fragmented (Stepanyan, 2003). The area of wintering of Oxyura leucocephala covers the countries of the Mediterranean, the Middle East and Central Asia, northern India and northern Africa. The results of winter bird counts indicate a reduction in their world population at the late XX century of more than 50\% (KreuzbergMukhina, 2002). Currently, Oxyura leucocephala is included on the IUCN Red List of Threatened Species with category «Endangered» (Endangered A2bcde + 4bcde) (BirdLife International, 2017).

In Southern Russia Oxyura leucocephala belongs to the regularly nesting species of the Volgograd region (Bukreev \& Chernobay, 2011) and it also breeds in small numbers in Stavropolsky Krai and Krasnodarsky Krai, Dagestan and Kalmykia (Kazakov et al., 2004; Badmaev, 2013; Khokhlov \& Il'yukh, 2013). In addition, in the late XX - early XXI century, there is an increase in the number of records of Oxyura leucocephala in the Crimea, where now it is a rare migratory, wintering, summer visitor and breeding species (Andryushchenko et al., 2013). Oxyura leucocephala was not registered on the Black Sea coast of the Caucasus before the 1990s.
We conducted regular (in all seasons of the annual cycle) avifaunistic surveys of the Black Sea coast of Abkhazia, as well as the southwestern part of the Russian Federation within the Tuapse region and City of Sochi between 1981 and 2018. During this time, 29 records of Oxyura leucocephala were registered mainly in the winter and migration periods. Oral reports of photographers, birdwatchers and colleagues (11 cases in total) on the observations of these white-headed ducks on the designated territory were also used.

For the first time Oxyura leucocephala (two individuals) was marked by us on the Black Sea coast of the Caucasus on the Inkit Lake near Pitsunda in the western part of Abkhazia on 15.04.1991 and 16.04.1991. At the beginning of the XXI century, records of Oxyura leucocephala began to acquire a regular character in this region.

From 2002 to 2011, eight cases of bird registrations were recorded on lakes near the sea coast on the territory of Abkhazia (Mayakskoe Lake near Sokhum, Skurcha Lake at the mouth of the Kodor River, Inkit Lake near Pitsunda), three of which - in winter, three - in late autumn and two - in early spring. Individuals and groups of three to ten white-headed ducks were observed (Table).

In 2007, Oxyura leucocephala was first discovered on the Black Sea coast of the Krasnodar- 
sky Krai in May (Tilba, 2007) and June (Khokhlov \& Il'yukh, 2007) on the lakes of the Imeretinskaya lowland (Sochi, Russia). One individual of Oxyura leucocephala was seen there by A.D. Lipkovich (oral report) on 31.12.2008.

Later, in 2016 (Shagarov, 2016), and mainly, in 2017, we noted a well-marked wintering of Oxyura leucocephala in the territory of the natural ornithological park in the Imeretinskaya lowland (Sochi, Russia) (Fig. 1). The regular presence of Oxyura leucocephala with a total number of up to ten individuals was traced from
28.12.2016 to 18.05.2017, and all the individuals noted were females. Birds did not leave one of the lakes of the natural ornithological park with a total area of $0.05 \mathrm{~km}^{2}$ practically, where also Anas penelope Linnaeus, 1758 ( 16 individuals), Aythya fuligula Linnaeus, $1758(\sim 450$ individuals) and Fulica atra Linnaeus, 1758 ( 120 individuals) were observed. However, in the winter season 2017-2018, without significant and prolonged cooling in the region, Oxyura leucocephala was not observed on the lakes of the Imeretinskaya lowland.

Table. Records of Oxyura leucocephala on the Black Sea coast of the Caucasus

\begin{tabular}{|c|c|c|c|c|}
\hline Record place & Data & Description of water body & $\begin{array}{c}\text { Number and sex } \\
\text { of met birds }\end{array}$ & Information source \\
\hline Pitsunda, Inkit Lake (Abkhazia) & $15-16.04 .1991$ & $\begin{array}{l}\text { Lake with rare near-water vegetation, } \\
\text { located } 400 \mathrm{~m} \text { from the seashore }\end{array}$ & male and female & Malandzia, 2002 \\
\hline $\begin{array}{l}\text { Sokhum, Mayakskoe Lake } \\
\text { (Abkhazia) }\end{array}$ & 8.01 .2002 & $\begin{array}{l}\text { Lake with rare near-water vegetation, } \\
\text { located } 1 \mathrm{~km} \text { from the seashore }\end{array}$ & male & A.V. Ratia, oral report \\
\hline Pitsunda, Inkit Lake (Abkhazia) & 23.03 .2002 & $\begin{array}{l}\text { Lake with rare near-water vegetation, } \\
\text { located } 400 \mathrm{~m} \text { from the seashore }\end{array}$ & five males & $\begin{array}{l}\text { A.K. Shavlohov, oral } \\
\text { report }\end{array}$ \\
\hline $\begin{array}{l}\text { Sokhum, Mayakskoe Lake } \\
\text { (Abkhazia) }\end{array}$ & 25.11 .2004 & $\begin{array}{l}\text { Lake with rare near-water vegetation, } \\
\text { located } 1 \mathrm{~km} \text { from the seashore }\end{array}$ & $\begin{array}{l}\text { two males and six } \\
\text { females }\end{array}$ & Authors' observations \\
\hline $\begin{array}{l}\text { Sokhum, Mayakskoe Lake } \\
\text { (Abkhazia) }\end{array}$ & 25.11 .2004 & $\begin{array}{l}\text { Lake with rare near-water vegetation, } \\
\text { located } 1 \mathrm{~km} \text { from the seashore }\end{array}$ & $\begin{array}{l}\text { about ten indi- } \\
\text { viduals }\end{array}$ & A.V. Ratia, oral report \\
\hline $\begin{array}{l}\text { Sokhum, Mayakskoe Lake } \\
\text { (Abkhazia) }\end{array}$ & 27.11 .2004 & $\begin{array}{l}\text { Lake with rare near-water vegetation, } \\
\text { located } 1 \mathrm{~km} \text { from the seashore }\end{array}$ & one individual & $\begin{array}{l}\text { A.N. Ivanitsky, oral } \\
\text { record }\end{array}$ \\
\hline Pitsunda, Inkit Lake (Abkhazia) & 28.01 .2006 & $\begin{array}{l}\text { Lake with rare near-water vegetation, } \\
\text { located } 400 \mathrm{~m} \text { from the seashore }\end{array}$ & one individual & $\begin{array}{l}\text { A.K. Shavlohov, oral } \\
\text { report }\end{array}$ \\
\hline $\begin{array}{l}\text { Adler district, Sochi, Imeretins- } \\
\text { kaya lowland (Russia) }\end{array}$ & $\begin{array}{l}4.05 .2006 \\
1-2.06 .2006\end{array}$ & $\begin{array}{l}\text { Lake with thicket of reed and cattail } \\
\text { on the banks, located } 100 \mathrm{~m} \text { from the } \\
\text { seashore }\end{array}$ & female & $\begin{array}{l}\text { Tilba, } 2007 \\
\text { Khokhlov \& Il'yukh, } \\
2007\end{array}$ \\
\hline $\begin{array}{l}\text { Sokhum, Mayakskoe Lake } \\
\text { (Abkhazia) }\end{array}$ & 25.03 .2007 & $\begin{array}{l}\text { Lake with rare near-water vegetation, } \\
\text { located } 1 \mathrm{~km} \text { from the seashore }\end{array}$ & male & Authors' observations \\
\hline $\begin{array}{l}\text { Adler district, Sochi, Imeretins- } \\
\text { kaya lowland (Russia) }\end{array}$ & 31.12 .2008 & $\begin{array}{l}\text { Lake with rare near-water vegetation, } \\
\text { located } 500 \mathrm{~m} \text { from the seashore }\end{array}$ & female & Photo by A.D. Lipkovich \\
\hline $\begin{array}{l}\text { Kodor River, Skurcha Lake } \\
\text { (Abkhazia) }\end{array}$ & 4.12 .2011 & $\begin{array}{l}\text { Lake with a rare near-water vegetation, } \\
\text { located } 150 \mathrm{~m} \text { from the seashore }\end{array}$ & three individuals & Authors' observations \\
\hline Kerch Strait (Russia) & January 2013 & Sea strait & five individuals & $\begin{array}{l}\text { Solokha \& Lokhman, } \\
2017\end{array}$ \\
\hline Anapa (Russia) & January 2013 & $\begin{array}{l}\text { Plain site with thicket of reed } 800 \mathrm{~m} \\
\text { from the seashore }\end{array}$ & ten individuals & $\begin{array}{l}\text { Solokha \& Lokhman, } \\
2017\end{array}$ \\
\hline Taman Bay (Russia) & January 2014 & $\begin{array}{l}\text { Lake with rare near-water vegetation, } \\
\text { located } 50 \mathrm{~m} \text { from the seashore }\end{array}$ & two individuals & $\begin{array}{l}\text { Solokha \& Lokhman, } \\
2017\end{array}$ \\
\hline $\begin{array}{l}\text { Adler district, Sochi, Imeretins- } \\
\text { kaya lowland (Russia) }\end{array}$ & $18.01-24.03 .2016$ & $\begin{array}{l}\text { Lake with rare near-water vegetation, } \\
\text { located } 500 \mathrm{~m} \text { from the seashore }\end{array}$ & $\begin{array}{l}\text { single females } \\
\text { and pairs }\end{array}$ & Authors' observations \\
\hline $\begin{array}{l}\text { Adler district, Sochi, Imeretins- } \\
\text { kaya lowland (Russia) }\end{array}$ & $\begin{array}{l}27.12 .2016- \\
18.05 .2017\end{array}$ & $\begin{array}{l}\text { Lake with rare near-water vegetation, } \\
\text { located } 500 \mathrm{~m} \text { from the seashore }\end{array}$ & \begin{tabular}{|l|} 
pairs, single \\
females and \\
groups from six \\
to ten females, 20 \\
records in all \\
\end{tabular} & Authors' observations \\
\hline Novorossiysk (Russia) & $\begin{array}{l}27.03 .2017 \\
29.03 .2017\end{array}$ & Sea lagoon & male & $\begin{array}{l}\text { A.V. Popovich, oral } \\
\text { report }\end{array}$ \\
\hline Novorossiysk (Russia) & $11-23.02 .2018$ & Sea lagoon & $\begin{array}{l}\text { two females, four } \\
\text { records in all }\end{array}$ & Photo by I.P. Torgachkin \\
\hline
\end{tabular}


Oxyura leucocephala has appeared in the northwestern part of the Black Sea coast of the Krasnodarsky Krai recently. Five white-headed ducks were found in the Kerch Strait and ten individuals in the wetlands of Anapa in January 2013. Two birds were recorded in Taman Bay (Solokha \& Lokhman, 2017) in the winter of 2014. In addition, the individuals and pairs were observed in the Sudzhuk lagoon of Novorossiysk (oral reports by A.V. Popovich and I.P. Torgachkin) on 27.03.2017 and 29.03.2017, and also from 11.02.2018 to 23.02.2018 (Fig. 2).

Thus, at present Oxyura leucocephala began to appear periodically on the Black Sea coast of the Caucasus from the mouth of the
River Kodor in Abkhazia to the Taman Bay in the Krasnodarsky Krai (Fig. 3). Most bird registrations took place in winter and a smaller one - during the migration period.

In the late XX and early XXI centuries, Oxyura leucocephala was recorded in winter also in the coastal regions of the Crimea. On the basis of the observations of 1990-2011 it was believed that the wounded and weakened birds were left to winter (Grinchenko, 2011). However, according to other sources, Oxyura leucocephala winters in various parts of the Crimea periodically, and white-headed ducks were observed there in 2013 regularly (Andryushchenko et al., 2013).

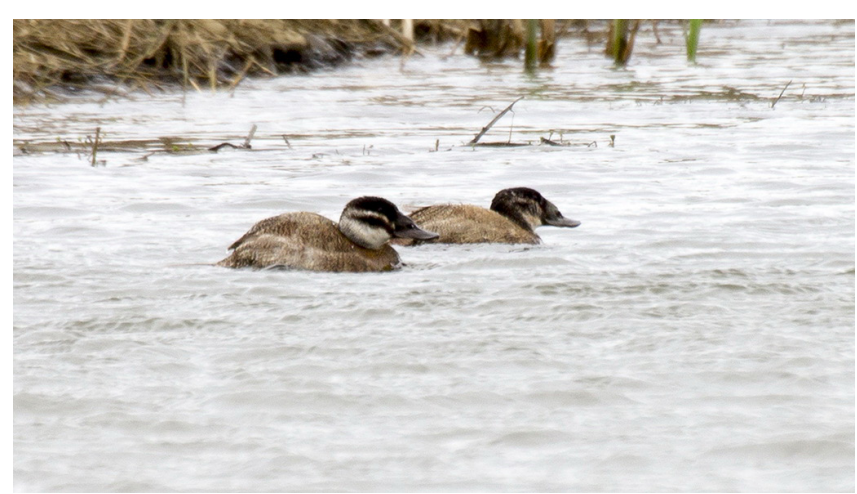

Fig. 1. Two females of Oxyura leucocephala in the natural ornithological park in the Imeretinskaya lowland (Sochi, Russia). Photo: Lev M. Shagarov.

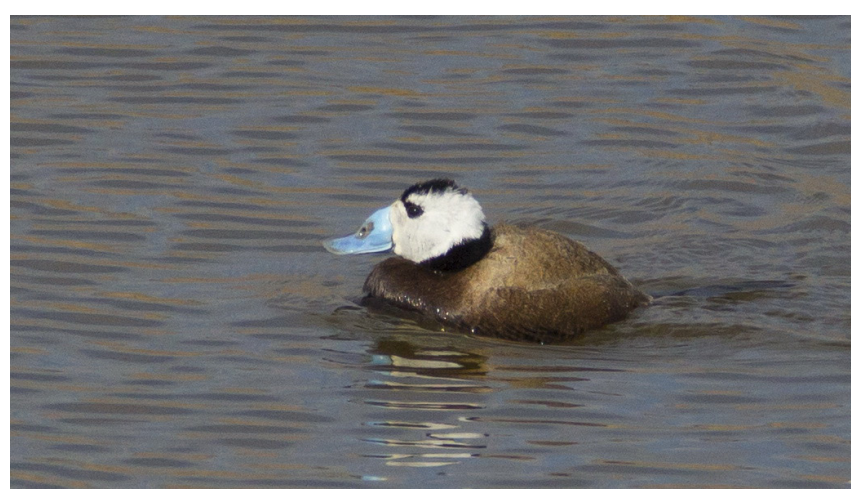

Fig. 2. Male of Oxyura leucocephala in the Sudzhuk lagoon of Novorossiysk (Russia). Photo: Anton V. Popovich.

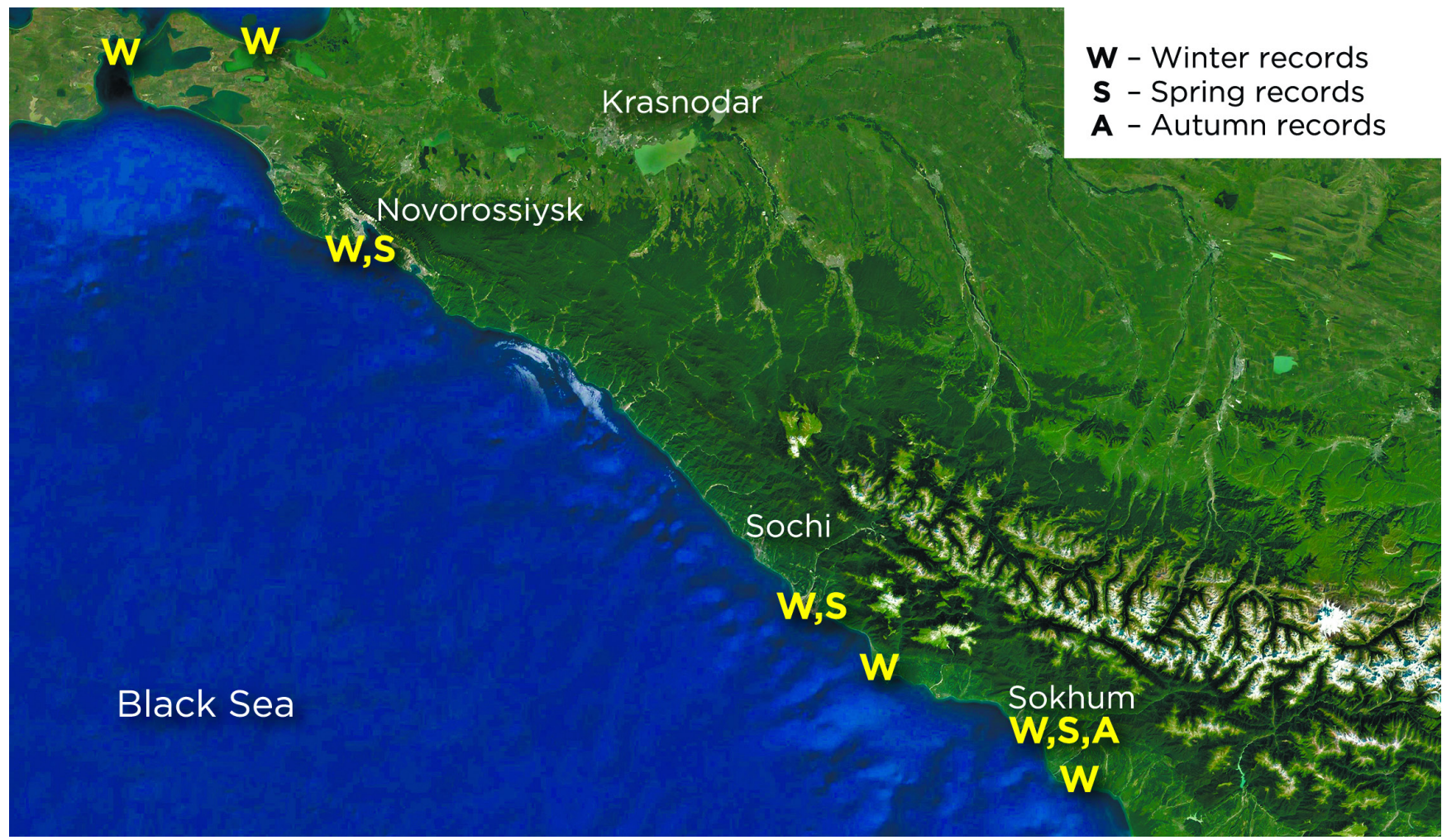

Fig. 3. Records of white-headed duck on the Black Sea coast of the Caucasus. 
Winter habitats of Oxyura leucocephala are large open water bodies, lakes, sea bays, more often with rocky shores (Isakov, 1952). In Uzbekistan birds were observed in the deep-water parts of lakes far from the coasts (KreuzbergMukhina, 2002). In other regions, for example, in the Middle East (Israel) wintering Oxyura leucocephala (according to December observations in 2009) adhered to lakes, as well as artificial reservoirs of fresh water - reservoirs devoid of aquatic vegetation. It is noted that fish-breeding ponds along the Mediterranean coast have lost their attraction for wintering birds (Rozenfeld \& Popovkina, 2012).

As a rule the white-headed ducks usually use for wintering small lakes of natural or artificial origin with rare coastal near-water vegetation located in the immediate vicinity of the shoreline of the Black Sea of the Caucasus. Less often they were noted in the sea bays and in the smooth sites (Table). There are no changes in the appearance of their habitats here. Similar habitats are also used by birds in the southern part of the Crimea. In particular, the white-headed ducks were recorded mainly in small inland water bodies with a lack of above-water vegetation and located up to $10 \mathrm{~km}$ from the shore of the sea, as well as in the sea bays and in the floods (Grinchenko, 2011; Andryushchenko et al., 2013).

The appearance and regular registrations of Oxyura leucocephala testify to the formation of a new wintering area of this species located north of the main places of its winter stay on the Black Sea coast of the Caucasus and in the Crimea. Perhaps this is due to the redistribution of birds occurring in other regions, particularly in the Mediterranean (Kreuzberg-Mukhina, 2002) and in Turkey (BirdLife International, 2017). Apparently, the low number of Oxyura leucocephala is explained both by their stay in the peripheral part of the wintering area, and by the recent appearance of this wintering site, which is currently at the formation stage. We believe it is for this reason that the presence of Oxyura leucocephala in typical habitats on the Imeretinskaya lowland has not been an annual occurrence yet.

\section{Acknowledgements}

The authors are grateful to Anton Popovich for interesting observations in Novorossiysk (Russia). We thank Anatoliy A. Khapugin for help in the manuscript editing and Anna V. Gubina for translating the paper (both - Joint Directorate of the Mordovia State Nature Reserve and National Park «Smolny», Russia).

\section{References}

Andryushchenko Yu.A., Atemasov A.A., Banik M.V., Beskaravaynyi M.M., Vergeles Yu.I., Kostin S.Yu., Kucherenko V.N., Popenko V.M., Prokopenko S.P. 2013. The white-headed duck (Oxyura leucocephala) in the Crimea. Kasarka 16: 70-84. [In Russian]

Badmaev I.B. 2013. White-headed duck. In: V.M. Muzaev (Ed.): Red Data Book of Republic of Kalmykia. Vol. 1. Animals. Elista. P. 120-121. [In Russian]

BirdLife International. 2017. Oxyura leucocephala. In: The IUCN Red List of Threatened Species 2017: e.T22679814A119403602. Available from: http:// dx.doi.org/10.2305/IUCN.UK.2017-3.RLTS. T22679814A119403602.en. Retrieved on 15.05.2018.

Bukreev S.A., Chernobay V.F. 2011. Data on Anseriformes of the Volgograd Sarpa. Kasarka 14: 223-239. [In Russian]

Grinchenko A.B. 2011. Migration and wintering of the White-headed Duck (Oxyura leucocephala) in the Crimea. Branta 14: 112-116. [In Russian]

Isakov Yu.A. 1952. Subfamily Anatinae. In: G.P. Dementyev, N.A. Gladkov (Eds.): Birds of the Soviet Union. Vol. 4. Moscow: Sovetskaya Nauka. P. 344-635. [In Russian]

Kazakov B.A., Lomadze N.H., Belik V.P., Khokhlov A.N., Tilba P.A., Pishvanov Ju.V., Prilutskaja L.I., Komarov Ju.E., Polivanov B.M., Emtyl M.H., Bicherev A.P., Oleynikov N.S., Zabolotny N.L., Kukish A.I., Mjagkova Ju.Ja., Tochiev T.Ju., Gizatulin I.I., Vitovich O.A., Dinkevich M.A. 2004. Birds of the North Caucasus. Vol. 1. Rostov-on-Don: RSPU. 398 p. [In Russian]

Khokhlov A.N., Il'yukh M.P. 2007. Spring-summer bird watching on the territory of Imeretinskaya Lowland. Caucasian Ornithological Herald 19: 125-137. [In Russian]

Khokhlov A.N., Il'yukh M.P. 2013. White-headed duck. In: A.A. Likhovid (Ed.): Red Data Book of Stavropolsky Krai. Stavropol: Asterisk. P. 171. [In Russian]

Kreuzberg-Mukhina E.A. 2002. Review of the current status of the Eastern populations of the white-headed duck. Kasarka 8: 277-294. [In Russian]

Malandzia V.I. 2002. Vagrant white-headed duck Oxyura leucocephala on coast of the Black Sea. Caucasian Ornithological Herald 4(2): 165. [In Russian]

Rozenfeld S.B., Popovkina A.B. 2012. The white-headed duck (Oxyura leucocephala) in Israel: the history and resent status of the wintering population. Kasarka 15(1): 99-105. [In Russian]

Shagarov L.M. 2016. Transformation of the Avifauna on Imeretinskaya Lowland after Sochi 2014 Olympic and Paralympic Games. Central European Journal of Zoology 3(2): 40-50. DOI: 10.13187/cejz.2016.3.40

Solokha A., Lokhman Y. 2017. Numbers and distribution of wintering waterbirds in the Krasnodar Province, southwestern Russia. Vogelwelt 137: 156-161.

Stepanyan L.S. 2003. Synopsis of the ornithological fauna of Russia and adjacent territories. Moscow: Akademkniga. 808 p. [In Russian]

Tilba P.A. 2007. Some rare and insufficiently studied bird species in the Southeast part of Krasnodar Region. Strepet 5(1-2): 5-18. [In Russian] 


\title{
OXYURA LEUCOCEPHALA (ANATIDAE: ANSERIFORMES)
} НА ЧЕРНОМОРСКОМ ПОБЕРЕЖЬЕ КАВКАЗА

\author{
П. А. Тильба ${ }^{1}$, Л. М. Шагаров ${ }^{2,3}$, В. И. Маландзия ${ }^{4}$ \\ ${ }^{1}$ Сочинский нацииональнылй парк, Россия \\ e-mail:ptilba@mail.ru \\ ${ }^{2}$ Природный орнитологический парк в Имеретинской низменности, Россия \\ ${ }^{3}$ Филиал Института природно-технических систем, Россия \\ e-mail:lev049@mail.ru \\ ${ }^{4}$ Абхазский государственный университет, Республика Абхазия \\ e-mail:malandzia@mail.ru
}

Приведены новые сведения о распространении савки Oxyura leucocephala на Черноморском побережье Кавказа. Первое появление вида в этом регионе зарегистрировано в 1991 г. В настоящее время савка является малочисленным зимующим и пролетным видом, встречающимся на Черноморском побережье Краснодарского края (Россия) и Абхазии. Обычно отмечаются одиночные особи или пары птиц, реже группы численностью до 10 уток. Наиболее выраженной была зимовка савок в 2016-2017 гг. на озерах природного орнитологического парка в Имеретинской низменности (Сочи, Россия). Высказывается предположение о формировании нового района зимовки савки, занимающего северо-восточное побережье Черного моря.

Ключевые слова: Абхазия, зимовка, Кавказ, миграция, Новороссийск, савка, Сочи, Черное море 